\title{
SOIL CHARACTERISTICS AND CLAY MINERALOGY OF TWO SUBALPINE FOREST SPODOSOLS WITH CLAY ACCUMULATION IN TAIWAN
}

\author{
Jen-Chyi Liu' and Zuens-Sans Chen ${ }^{2}$
}

Two Spodosols with significant spodic morphological characteristics and clay accumulation were selected from a subalpine forest region where the elevation ranges from 2400 to 2700 meters, with high precipitation and low temperatures, and cool and humid weather conditions prevail. The objectives of this study were to investigate the soil characteristics, weathering patterns of clay mineralogy, and genesis of the two Spodosols with clay accumulation in the Chunta Mountain region of central Taiwan. We have also proposed modification of the description of Spodosols in Soil Taxonomy. Soil characteristics, clay distribution, low soil $\mathrm{pH}$, and very low base saturation percentages caused by strongly leaching processes indicate that podzolization and clay illuviation are the pedogenic processes in the study area. The subsurface horizons of the two Spodosols meet the chemical criteria of the spodic horizon defined in Soil Taxonomy, which suggests that translocation of spodic materials has occurred. The value of organic carbon and Fep/Feo or Alp/Alo ratio reaches a profile maximum in the spodic horizon, which suggests that the spodic horizon was formed predominantly by the illuviation of organo-metallic complexes. Soluble organic matter leached with soil solutions along the soil pores from the upper horizons to the spodic horizon. The spodic horizon is characterized by many black and other dark pellets of organic matter. The clay mineralogy of the A and albic horizons is dominanted by illite, vermiculite and vermiculite-illite interstatified minerals (VI), but the Bhs horizons contain mainly vermiculite and hydroxy-interlayer vermiculite (HIV). The clay mineralogy of the eluvial horizons differs somewhat from that in the illuvial horizons as a result of moderate weathering. The weathering sequence of clay minerals in these two loamy Spodosols is: illite $\rightarrow$ vermiculite (or VI) $\rightarrow$ HIV. According to the USDA Soil Taxonomy, the two pedons with clay accumulation can be classified as a Typic Haplohumod and a Typic Haplorthod. (Soil Science 2004; Volume 169:66-80)

Key words: Spodosols, spodic horizon, podzolization, clay accumulation, soil micromorphology, clay mineralogy, weathering sequence.

$S^{\prime}$ PODOSOLS are characterized by a spodic horizon, which is dominated by active amorphous materials composed of organic matter and

\footnotetext{
'Dept. of Agricultural Chemistry, Taiwan Agricultural Research Institute, Wufens, Taichuns 413-01, Taiwan.

2Dept. of Agricultural Chemistry, National Taiwan University, Taipei 106-17, Taiwan. Dr. Chen is correspondins author. E-mail: soilchen@ccms.ntu.edu.tw

Received May 1, 2003; accepted Sept. 29, 2003

DOI: 10.1097/01.ss.0000112013.97541.74
}

aluminum, with or without iron (Freeland and Evans, 1993; Mokma, 1993; Soil Survey Staff, 1999). Generally, Spodosols are thought to be formed through dissolution in the upper horizons and translocation, transformation, and immobilization of organo-metallic complexes in the spodic horizon (Mokma, 1993).

Several processes have been proposed to explain podzolization: (i) formation and downward transport of complexes of organic acids with $\mathrm{Al}$ and Fe (De Coninck, 1980); (ii) silicate weather- 
ing followed by downward transport of $\mathrm{Al}$ and $\mathrm{Si}$ as inorganic colloidal sols (Jakobsen, 1991); and (iii) Al, and probably Fe, are first translocated into the B horizon as proto-imogolite soils (Farmer, 1982). While theories of illuviation of spodic materials have largely emphasized chemical processes rather than clay translocation, some studies have demonstrated clay particle as well as chemical migration of organo-metal complexes in podzolic soils or Spodosols (Fridland, 1958; Guillet et al., 1975; Alekseyev, 1983; Miller, 1983; Harris and Hollien, 1999; Hseu et al., 2004).

Spodosols of Taiwan are primarily on the Central Ridge, where the environmental conditions are characterized by cool and humid climate, level landscape position, and coniferous vegetation types (Chen, 1990; Liu and Chen, 1990; Li et al., 1998a; Lin et al., 2002). Different types of Spodosols have developed in the alpine and subalpine forest regions in Taiwan. In these regions, the development of Spodosols is limited by the high clay content in the soil pedon and the high slope of the landscape (Liu et al., 1994; Chen et al., 1995; Li et al., 1998a; Hseu et al., 2004).

Typical Spodosols have thick, white albic (E) horizons, and thin, dark red spodic horizons (Bhs) with spodic materials (Soil Survey Staff, 1999). These soils have low $\mathrm{pH}$ in the surface (A and $\mathrm{E}$ ) horizons and significant accumulations of $\mathrm{Fe}, \mathrm{Al}$, and organic carbon in the upper B horizons compared with the albic horizon. In Taiwan, the average clay content in the Bhs horizon is generally greater than $250 \mathrm{~g} / \mathrm{kg}$, and of clay, clay loam, silty clay loam, or loam texture. The parent materials of the Spodosols in Taiwan are sandstone, shale, or slate, which are easily weathered to finetextured soils. These loamy Spodosols or clayey Spodosols are quite different in morphology and properties from Spodosls in many other temperate climates of the world (Chen et al., 1995; Li et al., 1998a; Liu and Chen, 1998; Chiang et al., 1999; Lin et al., 2002; Hseu et al., 2004). Many papers have proposed that the criteria of Spodosols, especially for field morphology, should be modified to meet the characteristics of the spodic horizons that have high clay content in the B horizon of forest soils in Taiwan (Liu et al., 1994; Chen et al., 1995; Liu and Chen, 1998; Lin et al., 2002; Hseu et al., 2004).

The main features that have been noted in micromorphological studies of spodic horizons are monomorphic, polymorphic, cracked coatings with translocated organic matter, aluminum and iron, and pellety microstructure (McSweeney and FitzPatrick, 1990). The amorphous organic matter of spodic horizons can be divided into monomorphic matter, a continuous mass with uniform color and density, and polymorphic matter, a discontinuous mass with variable color and density (De Coninck, 1980; McKeague et al., 1983). Condron and Rabenhorst (1994) indicated that well drained soils show evidence of clay translocation in $\mathrm{B}$ and $\mathrm{BC}$ horizons through thin clay coating on grains and in voids, whereas somewhat poorly drained soils contain polymorphic organic-metal material in the voids of the spodic horizon.

The clay mineralogy of albic horizon in many Spodosols is dominated by vermiculite and/or smectite in temperate regions (Ross et al., 1990). Available information indicates that vermiculite and smectite in E horizons are formed from nonexpanding layer silicates, including illite, chlorite, and hydroxy-interlayered vermiculite (HIV) (Gjems, 1970; Chang, 1971; Ross and Kodama, 1974; Ross, 1975; Adams, 1976; Ross et al., 1990). Most Spodosols in Taiwan, however, lack smectite in the E horizon (Chen, 1973; Chen, 1990; Lin et al., 2002), except in some forest regions of central Taiwan (Li et al., 1998b). Thus, the objectives of this study are (i) to study the soil characteristics, macro- and micromorphology of the subalpine forest Spodosols with clay accumulation, (ii) to study the alteration and formation of clay minerals in two Spodosols with high clay content, and (iii) to study the pedogenic process in the study area.

\section{MATERIALS AND METHODS}

\section{Sampling Sites and Environmental Conditions}

Two loamy Spodosols were collected from an elevation of 2400 to 2700 meters along the Chungta forest region near Wanghsiang Mountain in central Taiwan $\left(23^{\circ} 37^{\prime} \mathrm{N}, 120^{\circ} 56^{\prime} \mathrm{E}\right.$ ) (Fig. 1). The environmental conditions of the study area include high precipitation $(3000 \mathrm{~mm} / \mathrm{yr})$, low temperature $\left(12.7^{\circ} \mathrm{C}\right)$, and high relative humidity (about 70\%), with cool and humid weather conditions. The soil moisture regime is udic, and the soil temperature regime is mesic. At present, the two pedons are covered with coniferous forest consisting of Taiwan red pine (Pinus taiwanensis), Chinese hemlock (Tsuga chinensis), and peacock pine (Cryptomeria japonica) species that were growing naturally in the field. Parent materials are mixed slate and sandstone. The soil texture classes of B horizons of selected soil pedons in the study area are clay loam or silty clay loam, with approximately $350 \mathrm{~g} / \mathrm{kg}$ of clay. 
Fig. 1. Two sampling sites of selected loamy Spodosols in central Taiwan.

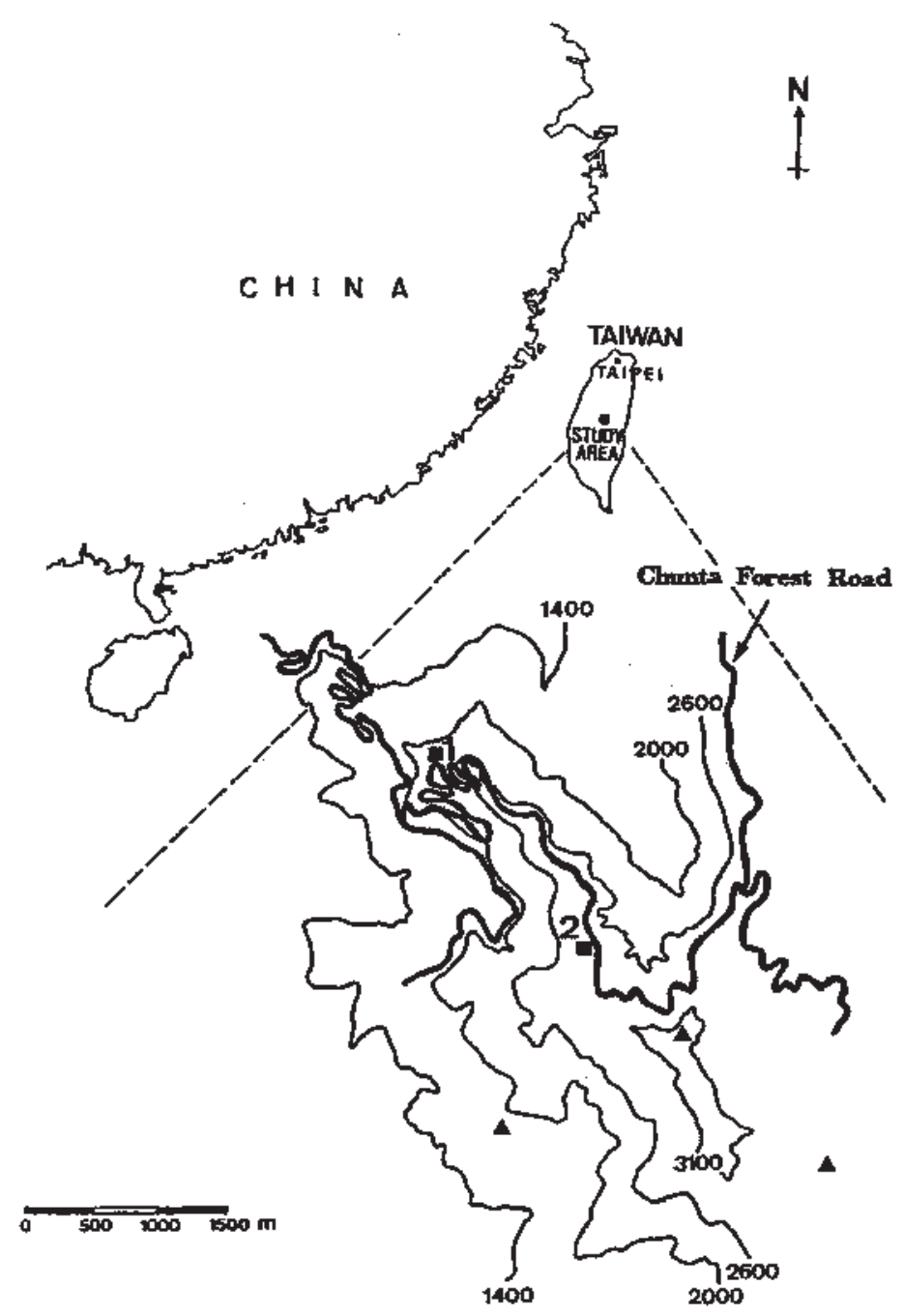

Soil Analysis

Soil samples were air-dried and partially ground to pass a $2-\mathrm{mm}$ sieve. Soil $\mathrm{pH}$ was determined by glass electrode in a soil/water ratio of 1:1 (McLean, 1982). Organic carbon was determined by the Walkley-Black wet combustion method (Nelson and Sommers, 1982). Particle size analysis was determined by the pipette method (Gee and Bauder, 1986). Exchangeable $\mathrm{K}, \mathrm{Na}, \mathrm{Ca}$, and $\mathrm{Mg}$ were exchanged by the ammonium acetate ( $\mathrm{pH}$ 7.0) method and determined by atomic adsorption spectrophotometry (Hitach 180-30 type) (Thomas, 1982). Exchangeable $\mathrm{Al}$ was determined by the Barnhisel and Bertsch (1982) method. Selected chemical properties of $\mathrm{Fe}$ and $\mathrm{Al}$ for each horizon were extracted with a dithionite-citrate-bicarbonate 
TABLE 1

The soil morphology of two soil pedons

\begin{tabular}{|c|c|c|c|c|c|c|c|}
\hline Horizon & $\begin{array}{l}\text { Depth } \\
(\mathrm{cm})\end{array}$ & $\begin{array}{l}\text { Munsell } \\
\text { color }{ }^{\dagger}\end{array}$ & Texture $\ddagger$ & Structure $\$$ & Consistance & Boundary \# & Root $\neq$ \\
\hline \multicolumn{8}{|c|}{ Pedon-1:2400 m } \\
\hline $\mathrm{O} / \mathrm{A}$ & $0-15$ & $\begin{array}{c}\text { 7.5YR 3/1(50\%) } \\
\text { 10YR 4/2(50\%) }\end{array}$ & $\mathrm{CL}$ & $2 f \& v f g r$ & fri & $\mathrm{cw}$ & $\mathrm{mf} \& \mathrm{~m}$ \\
\hline $\mathrm{E}$ & $15-33$ & $\begin{array}{l}\text { 10YR } 7 / 1(85 \%) \\
10 Y R 6 / 4(15 \%)\end{array}$ & $\mathrm{L}$ & mas\&2,1m\&fabk & $h, v h \& s \& p$ & $\mathrm{cw}$ & $m f \& v f$ \\
\hline $\mathrm{BE}$ & $33-47$ & $\begin{array}{c}7.5 \mathrm{YR} 5 / 8(75 \%) \\
10 \mathrm{YR} 6 / 4(25 \%)\end{array}$ & $\begin{array}{l}\mathrm{CL} \\
\mathrm{CL}\end{array}$ & mas\&2, $1 \mathrm{~m} \&$ fabk & h,vh\&s\&p & gw & mf\&vf \\
\hline Bhs & $47-63$ & $7.5 \mathrm{YR} 4 / 6$ & $\mathrm{SiCL}$ & 2 f\&vfgr, 2 f\&vfabk & fri\&ss\&sp & $\mathrm{d}$ & $m f \& v f$ \\
\hline Bs & $63-82$ & $7.5 \mathrm{YR} 4 / 6$ & $\mathrm{CL}$ & 2f\&vfgr, 3f\&vfabk & fri\&ss\&sp & $\mathrm{d}$ & $m f \& v f$ \\
\hline BC1 & $82-96$ & 10YR 5/8 & $\mathrm{CL}$ & $2 f \& v f g r$ & fri\&ss & $\mathrm{d}$ & $\mathrm{mf} \& \mathrm{vf}$ \\
\hline BC2 & $>96$ & $10 \mathrm{YR} 5 / 6$ & SCL & $2 f \& v f g r$ & fri\&ss & & ff\&vf \\
\hline \multicolumn{8}{|c|}{$\underline{\text { Pedon-2:2660 } \mathrm{m}}$} \\
\hline $\mathrm{O} / \mathrm{A}$ & $0-14$ & $7.5 \mathrm{YR} 3 / 1$ & $\mathrm{~L}$ & $3 f \& v f g r$ & vfri & $\mathrm{cW}$ & $m m \& f$ \\
\hline $\mathrm{E}$ & $14-22$ & $\begin{array}{l}\text { 10YR 7/1 } \\
\text { 7.5YR 6/6(mot) }\end{array}$ & $\mathrm{L}$ & $2 \mathrm{~m} \& \mathrm{fabk}, \mathrm{mas}$ & fir\&h\&vh & gw & $\mathrm{mf \& m}$ \\
\hline $\mathrm{BE}$ & $22-31$ & $\begin{array}{l}10 \mathrm{YR} 5 / 8 \\
7.5 \mathrm{YR} 6 / 1 \text { (mot) }\end{array}$ & $\mathrm{CL}$ & $2 \mathrm{f} \& \mathrm{vfabk}, 2 \mathrm{f} \& \mathrm{vfgr}$ & fir\&ss\&sp & gw & $\mathrm{mf} \& \mathrm{vf}$ \\
\hline Bhs & $31-45$ & $\begin{array}{l}7.5 \mathrm{YR} 4 / 6 \\
5 \mathrm{YR} 2.5 / 2(\mathrm{mot})\end{array}$ & $\mathrm{CL}$ & $2 f \& v f g r, 2 f \& v f a b k$ & fir & gw & $\mathrm{mf} \& \mathrm{vf}$ \\
\hline Bs1 & $45-60$ & $7.5 Y R 5 / 7$ & $\mathrm{CL}$ & 2f\&vfabk, 2 f\&vfgr & fir\&ss\&sp & $\mathrm{d}$ & $m f \& v f$ \\
\hline Bs2 & $60-85$ & $\begin{array}{l}\text { 10YR 5/6(60\%) } \\
10 Y R 5 / 8(40 \%)\end{array}$ & $\mathrm{CL}$ & 2f\&vfabk, $2 \mathrm{f} \& \mathrm{vfgr}$ & fir\&ss\&sp & $\mathrm{d}$ & mf\&vf \\
\hline Bs3 & $85-116$ & $10 Y R 5 / 7$ & CL & $2 \mathrm{f} \& \mathrm{vfabk}, 2 \mathrm{f} \& \mathrm{vfgr}$ & fir & $\mathrm{d}$ & fvf\&f \\
\hline $\mathrm{BC}$ & $>116$ & $10 Y R 5 / 6$ & SCL & $2 f \& v f g r$ & fri & & $\mathrm{ff}$ \\
\hline
\end{tabular}

t: $($ mot $)=$ mottles.

$\ddagger: \mathrm{L}=$ Loam, $\mathrm{CL}=$ Clay loam, $\mathrm{SiCL}=$ Silty clay loam, $\mathrm{SCL}=$ Sandy clay loam.

$\$: 1=$ strong, $2=$ moderate, $3=$ weak, $\mathrm{f}=$ fine, $\mathrm{vf}=$ very fine, $\mathrm{m}=$ medium, $\mathrm{c}=$ coarse, $\mathrm{gr}=$ granular, abk $=$ angular blocky, $\mathrm{sbk}=$ subangular blocky, $\mathrm{vc}=$ very coarse, mas $=$ massive.

ף: fri $=$ friable, $\mathrm{s}=$ sticky, $\mathrm{p}=$ plastic, $\mathrm{vs}=$ very sticky, $\mathrm{vp}=$ very plastic, fir $=$ firm, vh $=$ very hard, $\mathrm{h}=$ hard, $1=$ loose, $\mathrm{ss}$ $=$ slightly sticky, $\mathrm{sp}=$ slightly plastic.

\#: $\mathrm{g}=$ gradual, $\mathrm{w}=$ wave, $\mathrm{c}=$ clear, $\mathrm{d}=$ diffuse.

tt: $\mathrm{f}=$ few, $\mathrm{s}=$ some, $\mathrm{m}=$ many, $\mathrm{f}=$ fine, $\mathrm{m}=$ medium, $\mathrm{vf}=$ very fine, $\mathrm{c}=$ coarse, com $=$ common.

(DCB) (Mehra and Jackson, 1960), $0.2 \mathrm{M}$ oxalic acid (pH 3) (McKeague and Day, 1966), and 0.1 $M$ sodium pyrophosphate (pH 10) (Loveland and Digby, 1984). The optical density of oxalate extractable (ODOE) values was determined by spectrophotometer at $430 \mathrm{~nm}$ (Daly, 1982). The selected soil pedons were classified based on Soil Taxonomy (Soil Survey Staff, 1999).

\section{Semi-Quantitative Identification of Clay Minerals}

Air-dried samples were pretreated with 30\% $\mathrm{H}_{2} \mathrm{O}_{2}$ to remove organic matter and were then treated with DCB to remove the coating materials of oxides (Mehra and Jackson, 1960). The clay fraction was separated by the pipette method (Gee and Bauder, 1986). X-ray diffraction (XRD) analysis was performed on the oriented $\mathrm{K}$ - and $\mathrm{Mg}$-saturated clay samples. Clays were treated with $6 \mathrm{~N} \mathrm{HCl}$ to destroy the chlorite structure and for easy identification of vermiculite (Chen, 1977). Expansion properties of the $\mathrm{Mg}$-saturated samples were determined by ethylene glycol solvated at $65{ }^{\circ} \mathrm{C}$ for $24 \mathrm{~h}$. The K-saturated samples were further heated at $110{ }^{\circ} \mathrm{C}, 350{ }^{\circ} \mathrm{C}$, and $550{ }^{\circ} \mathrm{C}$ for $2 \mathrm{~h}$. The oriented clays were examined with an X-ray diffractometer (Rigaku Miniflex type) and Ni-filtered $\mathrm{Cu}-\mathrm{K} \alpha$ radiation generated at $30 \mathrm{kV}$ and $10 \mathrm{~mA}$. The XRD patterns were recorded ranging from 3 to $40^{\circ}(2 \theta)$ with a scanning speed of $0.5^{\circ}$ (2 $\theta)$ per minute. The identification and semiquantitative determination of the clay minerals are based on the differences of reflection patterns from the $\mathrm{K}$-saturated, Mg-saturated, glycolated, heated, and air-dried samples (Johns et al., 1954; Brindley, 1980). 


\section{RESULTS AND DISCUSSION}

$$
\text { Soil Morphology }
$$

Soil morphological characteristics of the two studied pedons are summarized in Table 1. The two selected soils have moderately good drainage and permeability conditions. The two pedons have the diagnostic Ochric epipedon with a dark organic/mineral (O/A) surface and diagnostic albic and spodic horizons. The moist color of the albic horizon is light gray (10YR 7/1) with some light yellowish brown (10YR 6/4) or reddish yellow (7.5YR 6/6) mottles. The color of the spodic horizon (Bhs) is 7.5YR 4/6 (strong brown). The spodic horizon has a fine and very fine angular blocky or granular structure. Both pedons are slightly sticky and plastic and have somewhat firm consistency in the Bhs horizon. The soil characteristics of the spodic materials of the two pedons indicate that the podzolization of this area is characterized by the illuviation of organometallic (Fe and/or Al) complexes or clay mixed with organo-metallic complexes (Table 1). In the field, we did not find the clear clay films observed in the lower part of the B horizons. The spodic horizons of the two pedons meet the soil morphology criteria of spodic materials of Spodosols defined in Soil Taxonomy (Soil Survey Staff, 1999).

\section{Soil Micromorphology}

The eluvial albic horizon of the two selected soils has a light color overlying the spodic horizon. The albic E horizon of the two pedons contains mineral grains with a wide range of sizes and without significant intergranular voids. It displays simple packing voids and also shows enaulic c/f related distribution, massive and pellicular grain microstructure without coating features on the grain surface. The clearly black and speckled amorphous objects are the organic matter in the $\mathrm{E}$ horizon. Mineral grains in the $\mathrm{E}$ horizon of Spodosols are virtually devoid of ferruginous coatings (De Coninck and McKeague, 1985).

The soil microstructure of the Bhs horizon, at a depth from 47 to $63 \mathrm{~cm}$ in pedon-1, is a compact grainy, spongy, cranular, and complex structure (Fig. 2). The intergranular spaces are densely infilled with weakly anisotropic, strong brown color to brown black color, granular, ovoid, or irregular shape materials. The granular material is composed mainly of organic matter, iron, clay, and few silt grains of quartz and mineral grain. The micromorphology of spodic horizons is characterized by the illuviation of a high quantity

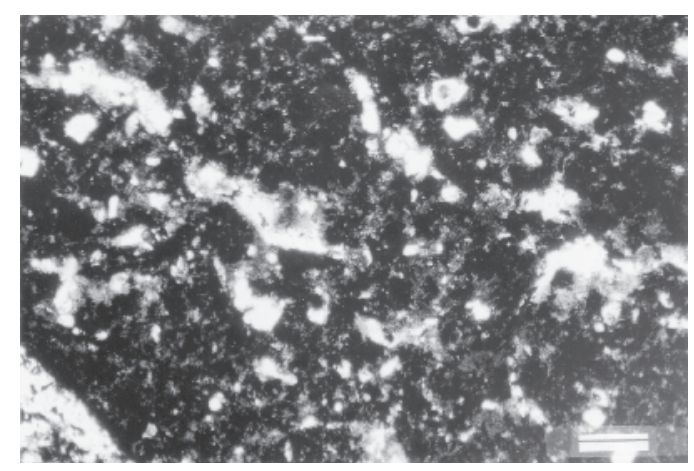

Fig. 2. Photomicrographs of a thin section indicated that high concentrations of organo-Fe complexes and mixed clay coating accumulated on soil grains in the Bhs horizon of pedon-1, plane polarized light (PPL), 40X, length of the bar is $0.25 \mathrm{~mm}$.

of organo-ferran, organs with some slightly oriented clay particle accumulated along the channels or voids (Fig. 2). There are few dark pellets and yellow clays found along the wall of voids. We also found many amorphous organic compounds leaching with soil solution along the soil pores from upper horizons to lower horizons as shown in Fig. 2. The micromorphology of the Bs horizon in pedon-1 indicates that significant and high amounts of dark pellets and organo-ferrans are distributed in the voids and oriented clay particle illuviated in the channels (Fig. 3). This micromorphology is evidenced by a yellower color and higher clay content than the albic E horizon.

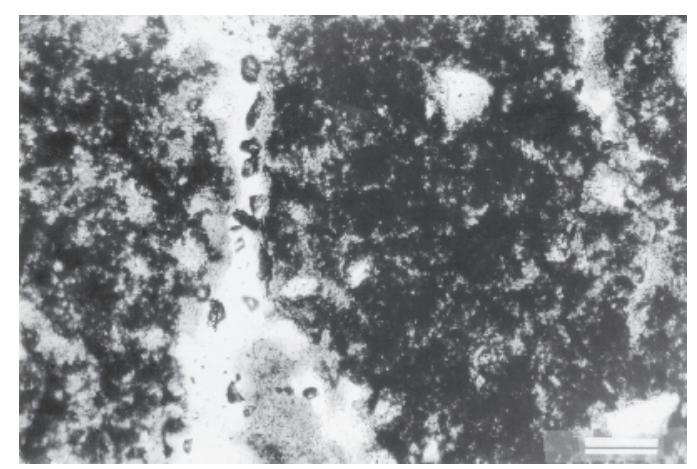

Fig. 3. Photomicrographs of a thin section indicate that high concentrations of organo-ferrans or organs accumulated on the clay particles or oriented clay distributed on the wall of voids in the Bs horizon of pedon-1; plane polarized light (PPL), 40X, length of the bar is $0.25 \mathrm{~mm}$. 
The organo-mineral material of pedon-2 can be either silt-sized or clay-sized matrix material mixed with polymorphic organic matter or organo-mineral weakly anisotropic coating (De Coninck, 1980). The plasma materials are mixed with polymorphic amorphous organic matter and fine grains (clay and silt), densely infilling in the soil voids, and form silt-sized dark grains in the Bhs horizon of pedon-2 (Fig. 4). From the photo, we can also observe pedofeatures such as voids, vughs, channels, chambers, and organoferran and slightly oriented clay coating in the thin section. The micromorphology of the Bs horizon in pedon-2 also indicates that significant and high amount of dark pellets and organoferrans distributed in the voids and oriented clay particle infilling on the channels (Fig. 5). The micromorphological characteristics of two pedons indicate that the argillans and organo-ferrans are found in the channels or voids, which indicates that the pedogenic process of clay illuviation and podzolocation occurred in the study area.

Wang and McKeague (1982) noted that translation of clay complexes with organic matter, Al, and Fe might cause a lack of well-oriented clay in spodic horizons despite the occurrence of large amounts of illuviated clay in Bhs horizons. In this study area of central Taiwan, isotropic illuvial clays are accumulated or mixed with organo-Fe complexes along the irregular voids in the Bhs horizons shown in Figs. 2 and 4 and Table 2. The micromorphological characteristics of the spodic horizons in two pedons show distinct dark pellets and oriented illuvial clays along the irregular voids. These results of this micro-
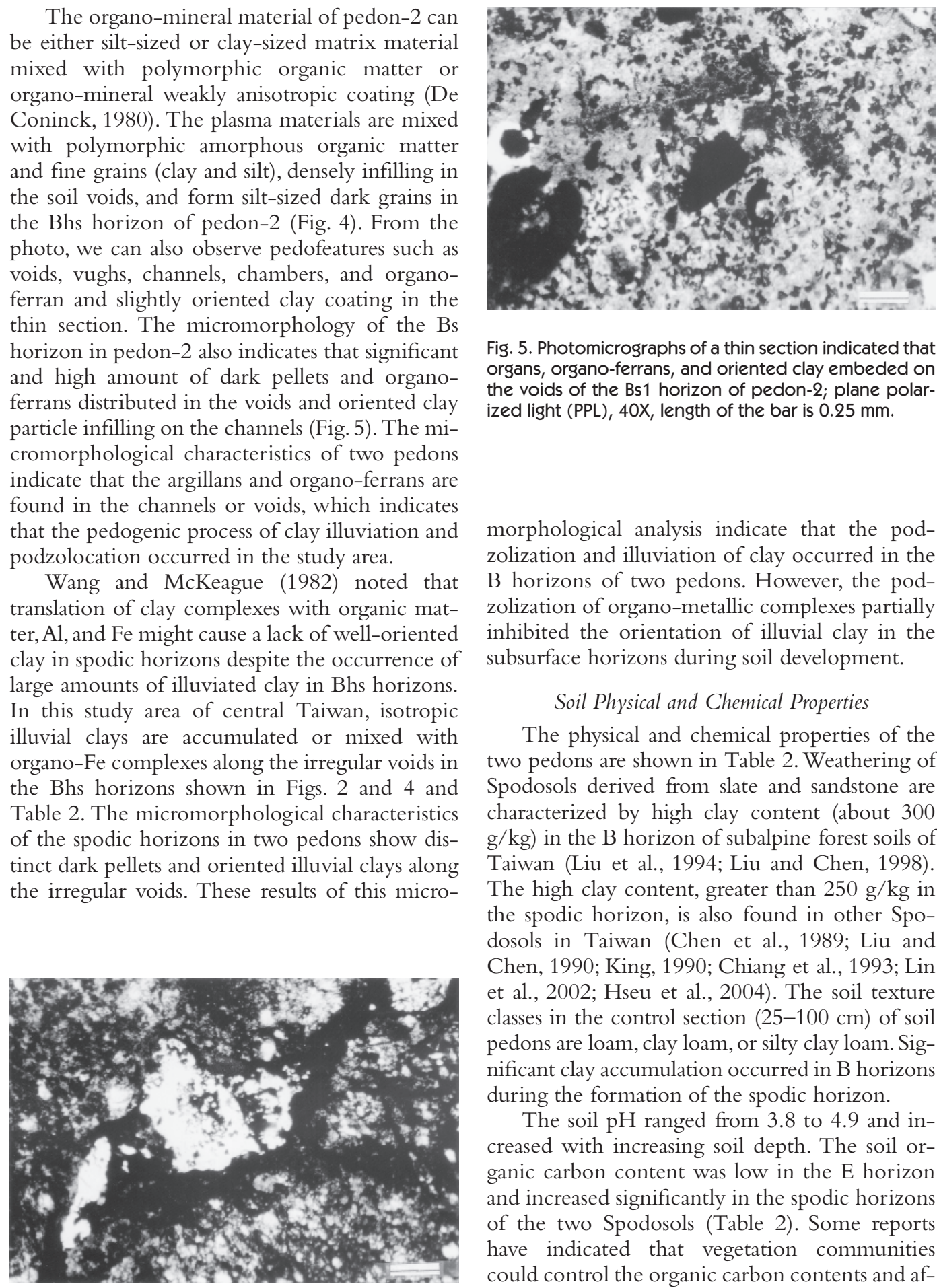

Fig. 5. Photomicrographs of a thin section indicated that organs, organo-ferrans, and oriented clay embeded on the voids of the Bs1 horizon of pedon-2; plane polarized light (PPL), 40X, length of the bar is $0.25 \mathrm{~mm}$.

morphological analysis indicate that the podzolization and illuviation of clay occurred in the B horizons of two pedons. However, the podzolization of organo-metallic complexes partially inhibited the orientation of illuvial clay in the subsurface horizons during soil development.

\section{Soil Physical and Chemical Properties}

The physical and chemical properties of the two pedons are shown in Table 2. Weathering of Spodosols derived from slate and sandstone are characterized by high clay content (about 300 $\mathrm{g} / \mathrm{kg}$ ) in the B horizon of subalpine forest soils of Taiwan (Liu et al., 1994; Liu and Chen, 1998). The high clay content, greater than $250 \mathrm{~g} / \mathrm{kg}$ in the spodic horizon, is also found in other Spodosols in Taiwan (Chen et al., 1989; Liu and Chen, 1990; King, 1990; Chiang et al., 1993; Lin et al., 2002; Hseu et al., 2004). The soil texture classes in the control section $(25-100 \mathrm{~cm})$ of soil pedons are loam, clay loam, or silty clay loam. Significant clay accumulation occurred in B horizons during the formation of the spodic horizon.

The soil $\mathrm{pH}$ ranged from 3.8 to 4.9 and increased with increasing soil depth. The soil organic carbon content was low in the E horizon and increased significantly in the spodic horizons of the two Spodosols (Table 2). Some reports have indicated that vegetation communities could control the organic carbon contents and affect the soil properties of Spodosols in central

Fig. 4. Photomicrographs of a thin section indicated that high concentrations of organo-ferrans, organs, or mixed clay accumulated on the wall of voids in the Bhs horizon of pedon-2; plane polarized light (PPL), 40X, length of the bar is $0.25 \mathrm{~mm}$. exchangeable cations and base saturation percentage $(\mathrm{BS} \%)$ in the two pedons are very low. Exchangeable aluminum and Al saturation per- 
TABLE 2

Physical and chemical properties of two pedons

\begin{tabular}{|c|c|c|c|c|c|c|c|c|c|c|c|}
\hline \multirow{2}{*}{ Horizon } & \multirow{2}{*}{ Depth } & \multicolumn{3}{|c|}{ Total } & \multirow{2}{*}{ Texture } & \multirow{2}{*}{$\begin{array}{c}\mathrm{pH} \\
\mathrm{H}_{2} \mathrm{O}\end{array}$} & \multirow{2}{*}{$\begin{array}{l}\text { Organic } \\
\text { carbon }\end{array}$} & \multirow{2}{*}{$\mathrm{CEC}^{\dagger}$} & \multirow{2}{*}{$\begin{array}{l}\text { Sum } \\
\text { cations }\end{array}$} & \multirow{2}{*}{$\begin{array}{l}\text { Base } \ddagger \\
\text { Satu. }\end{array}$} & \multirow{2}{*}{$\begin{array}{l}\text { Al§ } \\
\text { Satu. }\end{array}$} \\
\hline & & sand & silt & clay & & & & & & & \\
\hline & $\mathrm{cm}$ & $\ldots$ & $\mathrm{g} / \mathrm{kg}$ & & & & & $\mathrm{como}$ & -) $/ \mathrm{kg}$ & $\ldots$ & $\ldots$ \\
\hline \multicolumn{12}{|c|}{ Pedon-1: Fine, mixed, mesic, Typic Haplohumod } \\
\hline $\mathrm{O} / \mathrm{A}$ & $0-15$ & 367 & 337 & 296 & $\mathrm{CL}$ & 4.0 & 255 & 29 & 0.5 & 3 & 93 \\
\hline E & $15-33$ & 385 & 434 & 181 & $\mathrm{~L}$ & 4.1 & 8 & 6 & 0.1 & 2 & 95 \\
\hline $\mathrm{BE}$ & $33-47$ & 234 & 453 & 313 & CL & 4.2 & 31 & 20 & 0.2 & 1 & 98 \\
\hline Bhs & $47-63$ & 133 & 516 & 351 & $\mathrm{SiCL}$ & 4.4 & 85 & 34 & 0.3 & 1 & 97 \\
\hline Bs & $63-82$ & 232 & 406 & 362 & CL & 4.6 & 56 & 23 & 0.2 & 1 & 94 \\
\hline BC1 & $82-96$ & 360 & 296 & 344 & CL & 4.8 & 43 & 21 & 0.2 & 1 & 89 \\
\hline $\mathrm{BC} 2$ & $>96$ & 513 & 166 & 321 & SCL & 4.9 & 33 & 15 & 0.2 & 1 & 81 \\
\hline \multicolumn{12}{|c|}{ Pedon-2: Fine, mixed, mesic, Typic Haplorthod } \\
\hline $\mathrm{O} / \mathrm{A}$ & $0-14$ & 259 & 471 & 270 & $\mathrm{~L}$ & 3.8 & 394 & 54 & 1.6 & 3 & 78 \\
\hline E & $14-22$ & 343 & 386 & 271 & $\mathrm{~L}$ & 4.0 & 13 & 10 & 0.2 & 2 & 96 \\
\hline $\mathrm{BE}$ & $22-31$ & 338 & 343 & 319 & CL & 4.0 & 37 & 16 & 0.2 & 1 & 97 \\
\hline Bhs & $31-45$ & 322 & 320 & 358 & CL & 4.2 & 52 & 19 & 0.2 & 1 & 96 \\
\hline Bs1 & $45-60$ & 335 & 296 & 369 & CL & 4.4 & 19 & 16 & 0.1 & 1 & 97 \\
\hline Bs 2 & $60-85$ & 346 & 269 & 385 & CL & 4.6 & 24 & 13 & 0.1 & 1 & 97 \\
\hline Bs3 & $85-116$ & 391 & 280 & 329 & CL & 4.7 & 17 & 10 & 0.1 & 1 & 94 \\
\hline $\mathrm{BC}$ & $>116$ & 500 & 224 & 276 & SCL & 4.8 & 13 & 9 & 0.1 & 1 & 90 \\
\hline
\end{tabular}

†Cation exchangeable capacity.

故ase saturation percentage $(\%)=($ ex. bases $/$ CEC $) \times 100 \%$

$\mathbb{S} \mathrm{Al}$ saturation percentage $(\%)=[\mathrm{ex} . \mathrm{Al} /(\mathrm{ex} . \mathrm{Al}+$ ex. bases $)] \times 100 \%$

centages of the two soils are much higher than the sum of other cations, which indicates a strong leaching process in these soils.

Table 3 shows the three forms of extractable iron and aluminum in the two Spodosols. The maximum content of CBD-extractable iron $\left(\mathrm{Fe}_{\mathrm{d}}\right)$ is in the Bhs horizon of the two soils. The same trends are also found in the distribution of oxalate-extractable iron $\left(\mathrm{Fe}_{\mathrm{o}}\right)$ and pyrophosphateextractable iron (Fep). The contents of all three forms of extractable aluminum are similar to iron and are significantly increased in spodic horizons compared with the E horizon. Some studies have indicated that the high CBD-extractable iron content will strongly restrain the formation of a spodic horizon (Daly, 1982; Wang et al., 1989; Clayden et al., 1990). In this study, the ratio of free iron to clay tends to vary in the two pedons (Table 3). According to Soil Taxonomy (Soil Survey Staff, 1999), both clay and free iron can accumulate in the spodic horizon and in the argillic horizon. However, in well drained soils that have a spodic horizon, the ratio of free iron to clay tends to vary. In these two pedons, the $\mathrm{Fe}_{\mathrm{d}}$ /clay ratio reached a maximum in the Bhs horizons. This further confirmed that Spodosols occurred in the study area. The ratio of $\mathrm{Fe}_{\mathrm{p}} / \mathrm{Fe}_{\mathrm{o}}$ of the spodic horizons is about 2 , and the ratio of $\mathrm{Al}_{\mathrm{p}} / \mathrm{Al}_{\mathrm{o}}$ is close to 1 . These ratios indicate that most iron and aluminum existed as organometallic complexes in the selected soils (Liu and Chen, 1998, 2002).

Proposed chemical criteria for spodic materials meet the oxalate-extractable materials (Alo + $0.5 \mathrm{Fe}_{\mathrm{o}} \geq 0.5 \%$ and ODOE value $\geq 0.25$ ), and the value of the illuvial $\mathrm{B}$ horizon must be at least two times that of the overlying eluvial E horizon (Rourke, 1991). The two criteria values in the Bhs horizon of the two pedons also meet the chemical criteria, which suggests that spodic materials occurred in the selected pedons (Table 4). It is clear that the spodic materials and clay particles have accumulated in the Bhs horizons, which means that these soils can be classified as Spodosols with argillic horizons in the study area.

\section{Composition and Transformation of Clay Minerals}

The clay mineral composition and the distribution of the two Spodosols are summarized in Table 5. The XRD pattern of the O/A, E, Bhs, and $\mathrm{BC}$ horizons of two pedons are shown in Figs. 6 and 7. Vermiculite was characterized by a peak d-value of $1.4 \mathrm{~nm}$ at $25{ }^{\circ} \mathrm{C}$, collapsing to a $\mathrm{d}$-value of $1.0 \mathrm{~nm}$ when the $\mathrm{K}$-saturated clays 
TABLE 3

$\mathrm{Fe}$ and $\mathrm{Al}$ properties of soil pedons

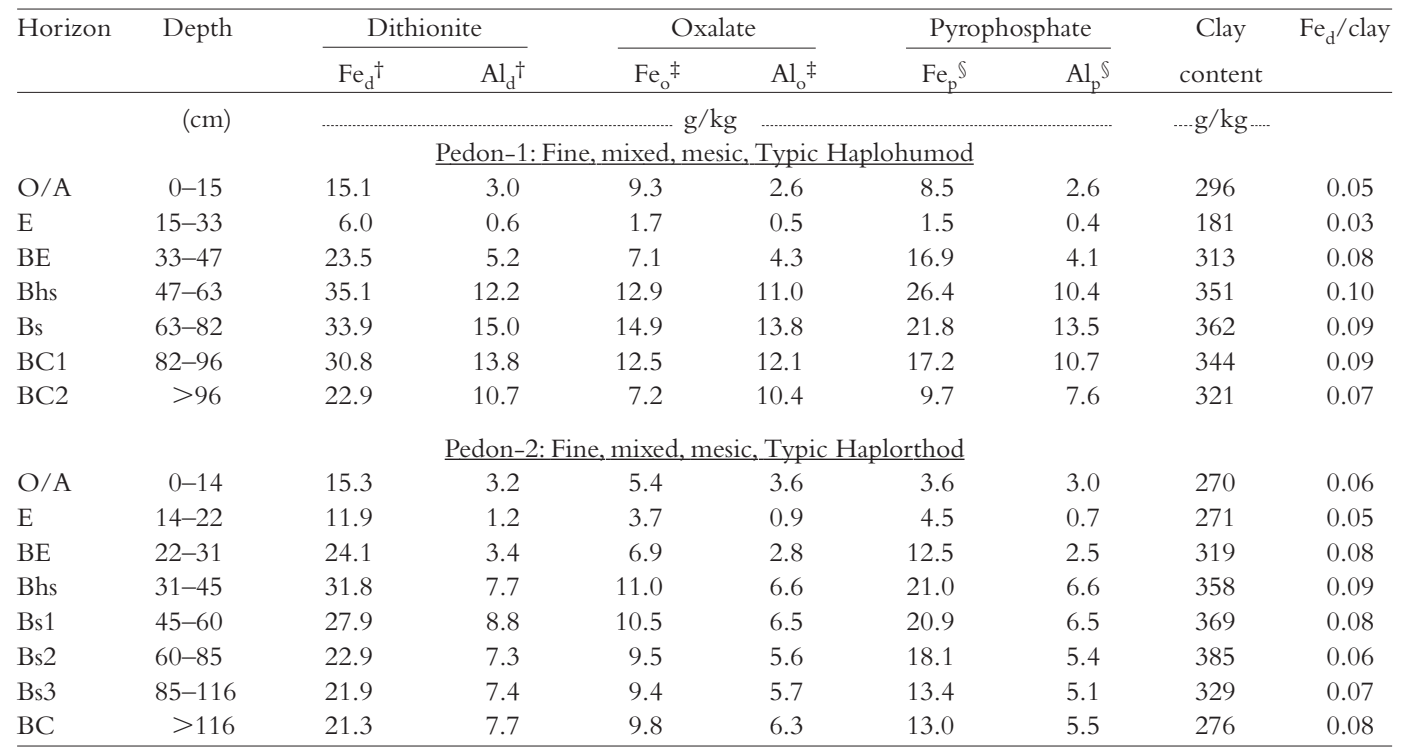

†Sodium citrate-bicarbonate-dithionite extractable iron and aluminum.

‡Oxalate-oxalic acid ( $\mathrm{pH} 3.0$ ) extractable iron and aluminum.

SSodium pyrophosphate ( $\mathrm{pH} 10)$ extractable iron and aluminum.

TABLE 4

Selected properties in $\mathrm{E}$ and Bhs horizons of two pedons

\begin{tabular}{|c|c|c|c|c|c|c|c|}
\hline Horizon & Depth & Munsell color & O.C. & $\mathrm{Fe}_{\mathrm{p}}^{\dagger}$ & $\mathrm{Al}_{p}^{\dagger}$ & $\mathrm{ODOE}^{\ddagger}$ & $\mathrm{Al}_{\mathrm{o}}+1 / 2 \mathrm{Fe}_{\mathrm{o}} \mathrm{S}$ \\
\hline & $(\mathrm{cm})$ & & $\mathrm{g} / \mathrm{kg}$ & $\ldots$ & 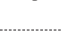 & & $\%$ \\
\hline \multicolumn{8}{|c|}{ Pedon-1: Fine, mixed, mesic, Typic Haplohumod } \\
\hline E & $15-33$ & 10YR 7/1(85\%) & 8 & 1.5 & 0.4 & 0.06 & 0.14 \\
\hline & & 10YR 6/4(15\%) & & & & & \\
\hline $\mathrm{BE}$ & $33-47$ & $7.5 \mathrm{YR} 5 / 8$ & 31 & 16.9 & 4.1 & 0.35 & 0.79 \\
\hline & & 10YR 6/4 (mottle) & & & & & \\
\hline Bhs & $47-63$ & $7.5 \mathrm{YR} 4 / 6$ & 85 & 26.4 & 10.4 & 2.08 & 1.74 \\
\hline Bs & $63-82$ & $7.5 \mathrm{YR} 4 / 6$ & 56 & 21.8 & 13.5 & 1.94 & 2.12 \\
\hline \multicolumn{8}{|c|}{ Pedon-2: Fine, mixed, mesic, Typic Haplorthod } \\
\hline $\mathrm{E}$ & $14-22$ & $10 Y R 5 / 8$ & 13 & 4.5 & 0.7 & 0.18 & 0.28 \\
\hline & & 7.5YR 6/1 (mottle) & & & & & \\
\hline \multirow[t]{2}{*}{$\mathrm{BE}$} & $22-31$ & 10YR 5/8 & 37 & 12.5 & 2.5 & 1.07 & 0.62 \\
\hline & & 7.5YR 6/1 (mottle) & & & & & \\
\hline Bhs & $31-45$ & $7.5 \mathrm{YR} 4 / 6$ & 52 & 21.0 & 6.6 & 1.82 & 1.21 \\
\hline & & 5YR $2.5 / 2$ (mottle) & & & & & \\
\hline Bs1 & $45-60$ & $7.5 \mathrm{YR} 5 / 7$ & 19 & 20.9 & 6.5 & 0.98 & 1.18 \\
\hline \multirow[t]{2}{*}{ Bs2 } & $60-85$ & 10YR 5/6(60\%) & 24 & 18.1 & 5.4 & 0.69 & 1.04 \\
\hline & & 10YR 5/8(40\%) & & & & & \\
\hline Bs3 & $85-116$ & $10 \mathrm{YR} 5 / 7$ & 17 & 13.4 & 5.1 & 0.55 & 1.04 \\
\hline
\end{tabular}

†Sodium pyrophosphate ( $\mathrm{pH} 10$ ) extractable aluminum and iron.

‡Optical density of oxalate extraction (ODOE).

$\$$ Oxalate extractable $\mathrm{Al}$ and $\mathrm{Fe}$. 
TABLE 5

Clay mineral compositiont of two pedons

\begin{tabular}{|c|c|c|c|c|c|c|c|c|c|c|}
\hline Horizon & Chl & Ver & HIV & Ill & $\mathrm{Sm}$ & V-I & $\mathrm{Kao}$ & $\mathrm{Qz}$ & Fld & Gib \\
\hline \multicolumn{11}{|c|}{ Pedon-1 } \\
\hline $\mathrm{O} / \mathrm{A}$ & - & ++ & - & ++ & - & + & + & + & + & - \\
\hline E & - & ++ & - & +++ & - & + & + & + & + & - \\
\hline $\mathrm{BE}$ & - & ++ & - & ++ & - & ++ & + & + & + & - \\
\hline Bhs & - & ++ & ++ & ++ & - & ++ & + & + & + & - \\
\hline Bs & - & + & ++ & ++ & - & ++ & + & + & + & + \\
\hline BC1 & + & + & ++ & ++ & - & + & + & + & ++ & + \\
\hline BC2 & + & + & ++ & +++ & - & + & - & + & ++ & - \\
\hline $\mathrm{C}^{\lessgtr}$ & - & - & - & +++ & - & - & - & - & + & - \\
\hline \multicolumn{11}{|c|}{$\underline{\text { Pedon-2 }}$} \\
\hline $\mathrm{O} / \mathrm{A}$ & - & + & - & ++ & - & + & + & + & + & + \\
\hline E & - & + & - & ++ & - & + & + & + & + & + \\
\hline $\mathrm{BE}$ & - & + & - & ++ & - & + & + & + & + & + \\
\hline Bhs & - & +++ & + & ++ & - & + & + & + & + & + \\
\hline Bs1 & - & ++ & + & ++ & - & + & + & + & + & + \\
\hline Bs2 & - & ++ & + & ++ & - & ++ & + & + & + & + \\
\hline Bs3 & + & ++ & + & +++ & - & + & + & + & + & + \\
\hline $\mathrm{BC}$ & + & + & + & +++ & - & + & + & + & + & + \\
\hline $\mathrm{C}^{\S}$ & - & - & - & +++ & - & - & - & - & + & - \\
\hline
\end{tabular}

†Chl: Chlorite, Ver: Vermiculite, HIV, Hydroxy interlayer Vermiculite, Ill: Illite, Sm: Smectite, V-I: vermiculite-illite interstratified mineral, Kao: Kaolinite, Qz: Quartz, Fld: Feldspar, Gib: Gibbsite.

I-: not detectable; $+:<10 \% ;++: 10-25 \% ;+++: 25-50 \%$.

SThe clay minerals of parent materials in the study area mainly composed with illite (Chen, 1969 \& 1973).

were heated at $110{ }^{\circ} \mathrm{C}$. Vermiculite-illite interstratified minerals were characterized by a basal XRD peak between $1.0 \mathrm{~nm}$ and $1.4 \mathrm{~nm}$ for $\mathrm{Mg}-$ saturated clays (Sawhney, 1989). Glycerol treatment does not alter the spacings, but with $\mathrm{K}$ saturation and heating to $100{ }^{\circ} \mathrm{C}$, the layers of the vermiculite component collapsed to illite, resulting in a $1.0-\mathrm{nm}$ peak and a series of higher orders. The broad peaks in this range indicated vermiculite-illite interstratified mineral existed in the O/A horizons. Gibbsite was reconfirmed by the peak $(0.485-\mathrm{nm})$, which disappeared when the $\mathrm{K}$-saturated clays of pedons were heated to $350{ }^{\circ} \mathrm{C}$. The $\mathrm{HCl}$ treatment without cationic saturation in this study was used to destroy the chlorite structure and to differentiate between chlorite and kaolinite.

Identification of hydroxy-interlayered vermiculite (HIV) was based on its failure to expand beyond XRD peaks of $1.4 \mathrm{~nm}$ after $\mathrm{Mg}$ saturation and glycerol solvating and its partial but incomplete collapse to $1.0 \mathrm{~nm}$ after $\mathrm{K}$ saturation and heat treatment (Harris et al., 1987; Rich, 1968). As a result, HIV was characterized by the collapse of the 1.4-nm peak in the XRD diagrams moving toward $1.0 \mathrm{~nm}$ when the $\mathrm{K}$ saturated clay samples were heated to $350{ }^{\circ} \mathrm{C}$.
The major clay minerals in the E horizon of two pedons were illite and vermiculite. Minor amounts of vermiculite-illite interstratified mineral, quartz, and kaolinite were identified. In the Bhs horizon of these two Spodosols, illite, vermiculite, and HIV were the main clay minerals. Minor amounts of kaolinite, quartz, and gibbsite were also present in the Bhs horizon. XRD patterns of the two Spodosols also indicate that illite and HIV are the dominant clay minerals in the BC horizon. According to basic geological studies in Taiwan, parent materials in this area are composed mainly of illite (Chen, 1969, 1973).

Previous studies have shown that the composition of soil solution derived from mica can drastically influence the nature of the weathering product (Vicente et al., 1977). High organic matter content and low soil $\mathrm{pH}$ of surface O/A horizons in two Spodosols indicate that organic acids have a high potential effect on the weathering products of clay minerals in the study area (Table 2). XRD patterns in $\mathrm{E}$ and $\mathrm{B}$ horizons of two pedons indicate that illite-vermiculite interstratified mineral may be derived from illite and vermiculite. Leaching processes and plant uptake can decrease the concentration of potassium in the soil solution. The potassium released from 

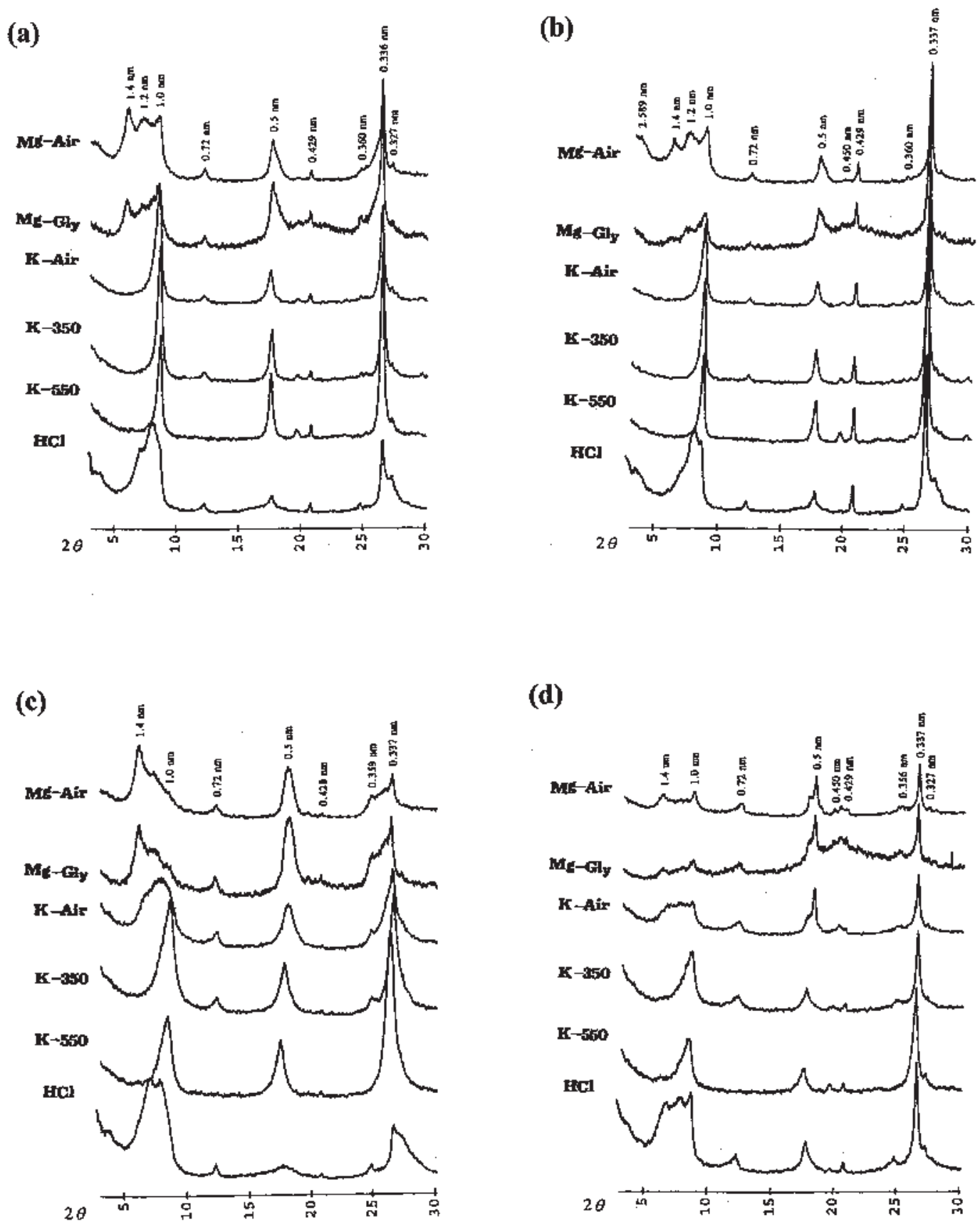

Fig. 6. X-ray diffraction patterns for clay fractions of different horizons in pedon-1: (a) O/A horizon, (b) E horizon, (c) Bhs horizon, and (d) BC horizon.

the interlayer of illite mineral promotes the formation of vermiculite. HIV formed in these two Spodosols can be regarded as a weathering product of illite or, more commonly, of the deposition of hydroxy-Al polymeric compounds within the interlayer of vermiculite. This proposal agrees with the results of previous studies (Gjems, 1963; Ross and Mortland, 1966; Malcolm et al., 1969; Adams, 1976; Barnhisel and Bertsch, 1989). 
(a)

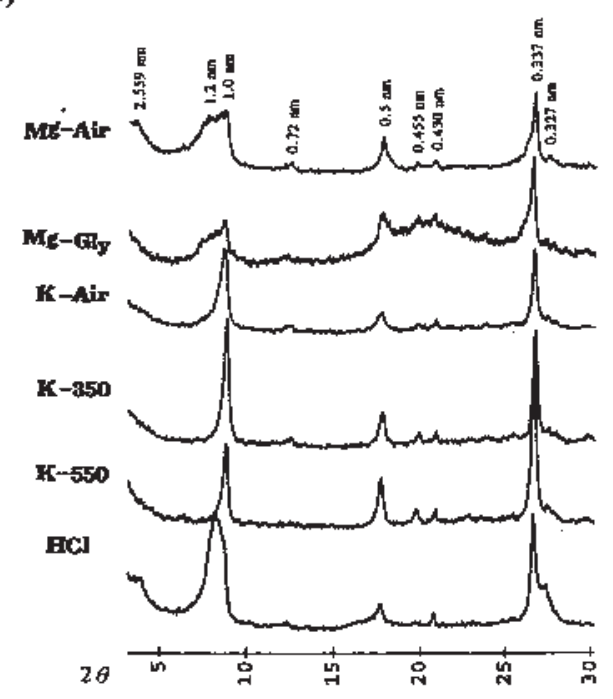

(c)

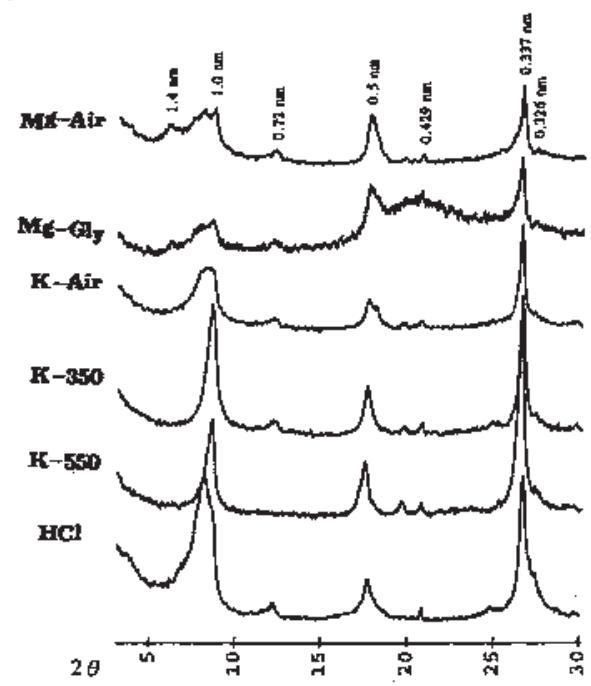

(b)

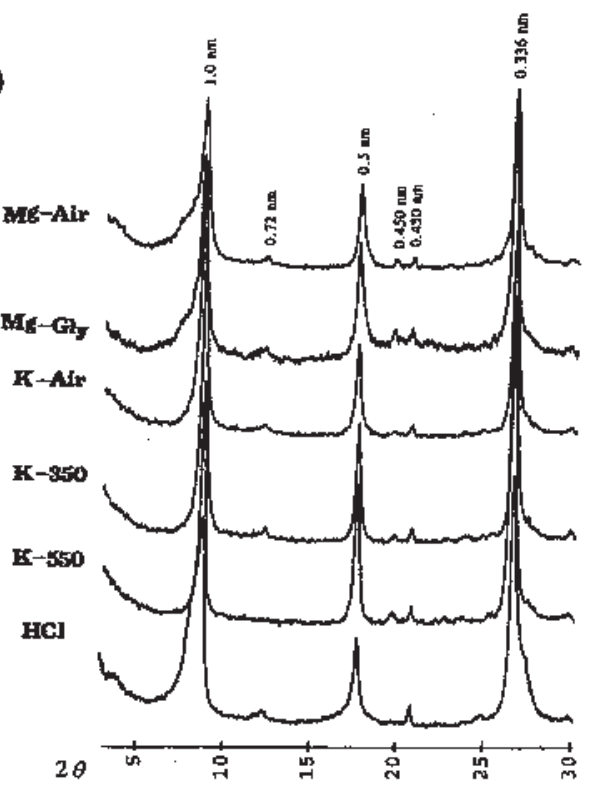

(d)

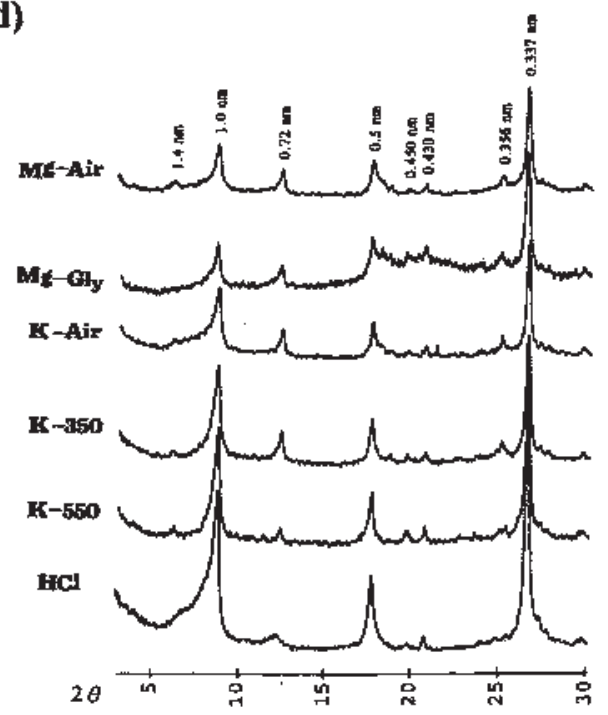

Fig. 7. X-ray diffraction patterns for clay fractions of different horizons in pedon-2: (a) O/A horizon, (b) E horizon, (c) Bhs horizon, and (d) BC horizon.

Weathering Sequence of Clay Minerals

Some water-soluble organic substances (especially for fulvic acid) formed from the litter decomposition of the upper part of the pedons, complexed with iron and aluminum, and then translocated into the spodic horizon of Spodosols (McKeague et al., 1983). The continuous removal of solubilized $\mathrm{Fe}$ and $\mathrm{Al}$ by leaching processes from the $\mathrm{E}$ horizon provides favorable conditions for weathering. 
The maximum amounts of illite were found in the $\mathrm{C}$ and $\mathrm{BC}$ horizons, but the amounts of vermiculite increased with decreasing soil depth (Table 5). A reverse trend occurred with illite and vermiculite throughout the soil profiles. This indicates that illite was transformed to vermiculite in this strong weathering environment. Fanning et al. (1989) indicated that illite was easily transformed to expansable 2:1 minerals, including vermiculite, and smectite was associated with the loss of $\mathrm{K}$ and the gain of hydrated exchangeable cations. Aluminum concentration is crucial to the transformation to smectite. Ismail (1970) reported that soils with low $\mathrm{Al}$ concentration and $\mathrm{pH}$ values above 6 or 7 favored the transformation of mica to smectite, but at a soil $\mathrm{pH}$ less than 6 , mica weathers to vermiculite. Therefore, based on soil $\mathrm{pH}$ less than 5.0, low contents of exchangeable $\mathrm{K}$, and relatively high extractable $\mathrm{Al}$ content in this condition (Table 2), illite gradually weathers to vermiculite, not to smectite, under good drainage and humid climate. The major phase of illite is dioctahedral, which is a source of aluminum and a precursor of HIV, kaolinite, and gibbsite.

In previous studies, we found relatively higher concentrations of pyrophosphate-extractable $\mathrm{Fe}-$, and/or Al-organic complexes formed in the Bhs horizon of Spodosols in central Taiwan near this study area (Li et al., 1998a and b; Lin et al., 2002). Some soluble aluminum was eluviated from the $\mathrm{E}$ horizon, illuviated into the interlayer of vermiculite in the Bhs horizon, and formed the HIV mineral (Ross, 1975; Gjems, 1970; Malcolm et al., 1969; Lin et al., 2002).

The clay minerals of the two loamy Spodosols indicate that illite is the dominant mineral in the parent materials (Li et al., 1998b; Lin et al., 2002). Podzolization occurred, including withdrawal of aluminum from the interlayers in the top soil and deposition of iron and aluminum ions, in combination with organic acid, in the Bhs horizon. This condition stabilizes the existing HIV minerals in the B horizons of the pedons. This proposal is supported by the following evidence: (i) there are no other detectable 2:1 minerals in the two pedons except vermiculite and illite; (ii) illuviation of spodic materials enriches the aluminum content to promote the formation of hydroxy-interlayer minerals in the B horizons; and (iii) when HIV was formed in the Bhs and Bs horizons, the metastable interlayered precipitates were presumably coated by the organo-metallic complexes and, thus, prevented from further weathering. Two hypotheses regarding the for- mation of HIV have been proposed by Barnhisel and Bertsch (1989): it could be a weathering product of chlorite, or, more commonly, it could be the result of formation of hydroxy-Al polymeric compounds within the interlayer spaces of vermiculite. We propose that the HIV in this study was derived from the formation of hydroxy-Al interlayers in vermiculite.

Aluminum species should occur largely in the form of $\mathrm{Al}^{3+}$ to allow insertion into the interlayer. Consequently, the very acidic condition ( $\mathrm{pH} 4.0$ to 4.1 ) is a reason that HIV was not detected by XRD in the E horizons. On the other hand, the release and loss of $\mathrm{Al}$ from the $\mathrm{E}$ horizon (relative lower contents of $\mathrm{Al}_{\mathrm{p}}$ and $\mathrm{Al}_{\mathrm{o}}$ ) (Table 3) and translocation downward resulted in HIV formation in the B horizon. The extremely low base saturation and good drainage conditions resulted in no smectite formation (Kittrick, 1971). Consequently, we propose that the weathering sequence of clay minerals in these two Spodosols is: illite $\rightarrow$ vermiculite (or vermiculiteillite interstratified minerals) $\rightarrow$ HIV .

This result also indicates that loamy Spodosols located at the subalpine forest region of central Taiwan are not similar to Spodosols formed in many other temperate climates of the world. We suggest that parent material composition and environmental conditions are the main factors that restrain the formation of smectite in the study area.

\section{Pedogenesis and Soil Classification}

Soluble organic acids were translocated from upper horizons with $\mathrm{Fe}, \mathrm{Al}$, and clay and formed organo-metallic complexs in Bhs horizons. The ratio of $(\mathrm{Fe}+\mathrm{Al}) / \mathrm{C}$ reached a level value, and the spodic materials precipitated in the spodic horizon. The spodic horizons have large amounts of clay and meet the criteria of argillic horizon defined in Soil Taxonomy (Soil Survey Staff, 1999). The illuviation of clay was leached from the upper E horizon. The soil micromorphologic features indicate the translocation of organic matter, iron or aluminum, and oriented clay formed in spodic horizons (Figs. 2, 3, 4, 5). The weak oriented clay found around grains of Bhs horizon implies that podzolization and illuviation of clay are pedogenic processes in the study area (Wang and McKeague, 1982).

According to Soil Taxonomy (Soil Survey Staff, 1999), the two soils can be classified as Spodosols (Tables 1 and 4). Soil moist color in the Bhs horizon is $7.5 \mathrm{YR} 4 / 6$ or $7.5 \mathrm{YR} 5 / 6$. The amorphous material content meets the proposed 
chemical criteria of $\mathrm{Al}_{\mathrm{o}}+0.5 \quad \mathrm{Fe}_{\mathrm{o}} \geq 0.5 \%$ and ODOE value $\geq 0.25$, and these two values of spodic horizons also meet at least two times or more compared with the overlying eluvial horizon of Spodosols. Because the organic carbon content is higher than $6 \%$ and the thickness of spodic horizon is more than $10 \mathrm{~cm}$ in pedon- 1 , the soil is classified as a Haplohumod. However, pedon-2 has only $52 \mathrm{~g} / \mathrm{kg}$ of organic carbon content in the Bhs horizon and is classified as Haplorthod.

\section{Recommendation on Soil Taxonomy}

We propose that the criteria of a spodic horizon defined in Soil Taxonomy (Soil Survey Staff, 1999), especially regarding soil morphology, should include Spodosols with higher clay content $(>250 \mathrm{~g} / \mathrm{kg})$ in the control section of soil pedons, which derive from slate, sandstone, or shale parent materials in Taiwan. We propose that "Ultic subgroup" should be included in the Great Group of Haplohumod that have clay illuviation in the spodic horizon.

\section{CONCLUSIONS}

Their high organic matter content and low soil $\mathrm{pH}$ indicate that organic acids are likely to have a strong affect in regard to weathering of products of clay minerals in the study area. Significant illuviation of active amorphous spodic materials and oriented clay has occurred in the spodic horizons of selected soils. According to soil morphology and laboratory characteristics, these two subalpine forest soils can be classified as loamy Spodosols (a Typic Haplohumod and a Typic Haplorthod) based on Soil Taxonomy (Soil Survey Staff, 1999). They have loamy or slightly clayey textures in spodic horizons. Some evidence of oriented clay is found along the irregular voids. We suggest that podzolization processes and illuviation of clay occurred from $\mathrm{E}$ horizons to Bhs horizons in the study area. According to Soil Taxonomy, the two selected subalpine forest soils can be classified as Typic Haplohumod or Typic Haplorthod. We propose that "Ultic subgroup" should be included in the Great Group of Haplohumod that has clay illuviation in the spodic horizon.

The major clay mineral of the E horizon in the two Spodosols was illite, and minor were vermiculite, mixed layer minerals, quartz, and kaolinite. In the Bhs horizon, illite, vermiculite, and $\mathrm{HIV}$ were the main clay minerals. The release of $\mathrm{K}$ from the interlayer of illite promotes the formation of vermiculite. HIV formed in these Spo- dosols can be regarded as a weathering products derived from chlorite or, more commonly, derived from the deposition of hydroxy-Al polymeric compounds within the interlayer of vermiculite. XRD patterns also indicated that illite, HIV, mixed layer minerals, and chlorite are the dominant clay minerals in the BC horizon. We suggest that the weathering pattern of clay minerals of two loamy Spodosols follows the sequence: illite $\rightarrow$ vermiculite (or vermiculite-illite interstratified minerals) $\rightarrow$ HIV.

\section{REFERENCES}

Adams, W. A. 1976. Experimental evidence on the origin of vermiculite in soils on lower Palaeozoic sediments. Soil Sci. Soc. Am. J. 40:793-796.

Alekseyev, V. Y. 1983. Mineralogical analysis for the determination of podzolization, lessivage and argillation. Sov. Soil Sci. 15:21-28.

Barnhisel, R. I., and P. M. Bertsch. 1982. Aluminum. In Methods of soil analysis, Part 2. Chemical and Microbiological Properties, 2nd Ed. Agronomy monogr. No. 9. A.L. Page et al. (eds.). ASA and SSSA, Madison, WI, pp. 275-300.

Barnhisel, R. I., and P. M. Bertsch. 1989. Chlorites and hydroxy-interlayered vermiculite and smectite. In Minerals in Soil Environments. 2nd Ed. J.B. Dixon and S.B. Weed (eds.). SSSA, Madison, WI, pp. 729-779.

Brewer, R. 1964. Fabric and Mineral Analysis of Soils. John Wiley \& Sons, New York.

Brindley, G. W. 1980. Quantitative X-ray mineral analysis of clays. In Crystal Structures of Clay Minerals and Their X-ray Identification. G.W. Brindley and G. Brown (eds.). Mineralogical Society, London, pp. 411-438.

Bullock, P., N. Fedoroff, A. Jongerius, G. Stoops, and T. Tursina. 1985. Handbook for Soil Thin Section Description. Waine Research Publications, Wolverhamption, UK.

Chang, J. M. 1971. Clay mineralogy and related chemical properties of podzolic soils in Taiwan. J. Chin. Agric. Chem. Soc. 9:36-48 (in Chinese, with English abstract and table).

Chen, P. Y. 1969. Primary research of clay mineral distribution in Taiwan. Newsletter of Soil and Fertilizer 218:1023-1025.

Chen, P. Y. 1973. Clay minerals and their distribution in Taiwan. Geology 1:41-52 (in Chinese, with English abstract and table).

Chen, P. Y. 1977. Table of key lines in X-ray powder diffraction patterns of minerals in clays and associated roaks. Printed by the authority of the state of Indiana, Bloomington, IN.

Chen, Z.S. 1990. Spodosols of Taiwan. In Proc. 5th Int. Soil Correlation Mtg. (V-ISCOM): Characterization, Classification and Utilization of Spodosols. J. M. Kimble and R. D. Yeck (eds.). USDA-SCS and 
Soil Management Support Service. Lincoln, NE, pp. 74-87.

Chen, Z. S., J. C. Liu, and H. C. Chiang. 1995. Soil properties, clay mineralogy, and genesis of some alpine forest soils in the Ho-Huan Mountain area of Taiwan. J. Chin. Agric. Chem. Soc. 33:1-17.

Chen, Z. S., K. C. Lin, and J. M. Chang. 1989. Soil characteristics, pedogenesis, and classification of $\mathrm{Be}-$ ichateinshan Podzolic soils, Taiwan. J. Chin. Agric. Chem. Soc. 27:145-155.

Chiang, H. C., M. K. Wang, K. H. Houng, G. N. White, and J. B. Dixon. 1999. Mineralogy of B horizons in alpine forest soils of Taiwan. Soil Sci. 164:111-122.

Chiang, H. C., Z. S. Chen, G. C. Lin and F. W. Horng. 1993. Morphology, Properties, and Classification of Forest Soils in High Mountains of Taiwan. Taiwan Forestry Research Institute, Taipei, Taiwan, ROC.

Clayden, B., B. K. Daly, R. Lee, and G. Mew. 1990. The nature, occurrence and genesis of placic horizons. In Proc. 5th Int. Soil Correlation Mtg. (V ISCOM): Characterization, Classification and Utilization of Spodosols. J.M. Kimble and R.D. Yeck (eds.). USDA-SCS and Soil Management Support Service. Lincoln, NE, pp. 88-104.

Condron, M. A. and M. C. Rabenhorst. 1994. Micromorphology of spodic horizons in a PsammentAquod toposequence on the Atlantic coastal plain of Maryland. In Soil Micromorphology: Studies in Management and Genesis. Proc. IX Int. Working Mtg. on Soil Micromorphology, Townsville, Australia, 1992. A. J. Ringrose-Voase and G. S. Humphreys (eds.). Developments in Soil Science 22, Elsevier, Amsterdam, pp. 179-186.

Daly, B. K. 1982. Identification of podzols and podzolized soils in New Zealand by relative absorbance of oxalate extracts of A and B horizons. Geoderma 28:29-38.

De Coninck, F. 1980. Major mechanisms in the formation of spodic horizons. Geoderma 24:101-128.

De Coninck, F., and J. A. McKeague. 1985. Micromorphology of Spodosols. In Soil Micromorphology and Soil Classification. L.A. Douglas and M.L. Thompson (eds.). SSSA, Madison, WI, pp. 121-144.

Fanning, D. S., V. Z. Keramidas, and M. A. El-Desoky. 1989. Micas. In Minerals in Soil Environments. J.B. Dixon and S.B. Weed (eds.). SSSA, Madison, WI, pp. 551-634.

Farmer, V. C. 1982. Significance of the presence of allophane and imogolite in Podzol Bs horizons for podzolization mechanism: A review. Soil Sci. Plant Nutr. 28:571-578.

Freeland, J. A., and C. V. Evans. 1993. Genesis and profile development of Success soil, Northern New Hampshire. Soil Sci. Soc. Am. J. 57:183-191.

Fridland, V. M. 1958. Podzolization and illimerization (clay migration). Sov. Soil Sci. 1:24-32.

Gee, G. W. and J. W. Bauder. 1986. Partical size analysis. In Methods of Soil Analysis, Part 1. Physical and Mineralogical Methods, 2nd Ed. Agronomy monogr. No. 9. A. Klute (ed.). ASA and SSSA, Madison, WI., pp. 383-411.

Gjems, O. 1963. A swelling dioctahedral clay mineral of a vermiculite-smectite type in the weathering horizons of podzols. Clay Miner. Bull. 5:183-193.

Gjems, O. 1970. Mineralogical composition and pedogenic weathering of the clay fraction in podzol soil profiles in Zalesine, Yugoslavia. Soil Sci. 110:237243.

Guillet, B., J. Rouiller, and B. Souchier. 1975. Podzolization and clay migration in Spodosols of eastern France. Geoderma 14:223-245.

Harris, W. G., V. W. Carlisle, and K. C. J. Van Rees. 1987. Pedon zonation of hydroxy-interlayered minerals in Ultic Haplaquods. Soil Sci. Soc. Am. J. 51:1367-1372.

Harris, W. G., and Hollien, K. A. 1999. Changes in quantity and composition of crystalline clay across E-Bh boundaries of Alaquods. Soil Sci. 164:602608.

Hseu, Z. Y., C. W. Lin, C. C. Tsai, and Z. S. Chen. 2004. Transitional soil characteristics between Ultisols and Spodosols in the subalpine forest of Taiwan. Geoderma (revised).

Ismail, F. T. 1970. Biotite weathering and clay formation in arid and humid region, California. Soil Sci. 109:257-261.

Jakobsen, B. H. 1991. Multiple processes in the formation of subarctic podzols in Greenland. Soil Sci. 152:414-426.

Johns, W. D., R. E. Grim, and W. F. Bradley. 1954. Quantitative estimation of clay minerals by diffraction methods. J. Sediment. Petrol. 24:242-251.

King, H. B. 1990. Genesis and classification of soils developed under the Yusan cane (Yushania niitakayamensis) grassland in the western Taroko National Park. Project report of Taroko National Park. Taiwan Forestry Research Institute, Taipei, Taiwan, ROC.

King, H. B. 1993. Pedogenesis and classification of soils developed under Taiwan Fir (Abies kawakamii) forest in the Ho-Huan mountain area. Q. J. Chin. For. 26:15-29.

Kittrick,J.A. 1971. Montmorillonite equilibria and the weathering environment. Soil Sci. Soc. Am. Proc. 35:815-820.

Li, S. Y., Z. S. Chen, and J. C. Liu. 1998a. Subalpine loamy Spodosols in Taiwan: Characteristics, micromorphology, and genesis. Soil Sci. Soc. Am. J. 62:710-716

Li, S. Y., Z. S. Chen, and J. C. Liu. 1998b. Weathering sequence of clay minerals in loamy Spodosols of central Taiwan. J. Agric. Assoc. China 183:51-68.

Lin, C. W., Z.Y. Hseu, and Z.S. Chen. 2002. Clay mineralogy of Spodosols with fine textures in the subalpine forest soils of Taiwan. Clays Clay Miner. 50:726-735

Liu, J. C., J. H. Yang, H. C. Chiang, H. Y. Guo, and Z. S. Chen. 1994. Properties, clay mineralogy and pe- 
dogenic processes of two mountain forest soils in Chi-Lan Area, Taiwan. J. Chin. Agric. Chem. Soc. 32:612-626 (in Chinese, with English abstract and table).

Liu, J. C., and Z. S. Chen. 1998. Soil characteristics and pedogenesis of loamy Spodosols near Wanghsiang mountain in central Taiwan. J. Chin. Agric. Chem. Soc. 36:151-162.

Liu, J. C., and Z. S. Chen. 2002. Characterization and genesis of Loamy Spodosols in subalpine forest soils of central Taiwan. In Proceedings of the 17th World Congress of Soil Science, August 14-21, 2002, Bangkok, Thailand, p. 968.

Liu, J. T. and Z. S. Chen. 1990. Characteristics, genesis and classification of podzolic soils in Tamanshan mountain, northern Taiwan. J. Chin. Agric. Chem. Soc. 28: 148-159 (in Chinese, with English abstract and table).

Loveland, P. J., and P. Digby. 1984. The extraction of Fe and Al by $0.1 M$ pyrophosphate solutions: A comparison of some techniques. J. Soil Sci. 35:243-250.

Malcolm, R. L., W. D. Nettleton, and R. J. McCracken. 1969. Pedogenic formation of montmorillonite from a 2:1-2:2 intergrade clay mineral. Clays Clay Miner. 16:405-414.

McKeague, J. A., and J. H. Day. 1966. Dithionite and oxalate extractable $\mathrm{Fe}$ and $\mathrm{Al}$ as acids in different various classes of soils. Can. J. Soil Sci. 46:13-22.

McKeague, J. A., F. De Coninck, and D. P. Franzmeier. 1983. Spodosols. In Pedogenesis and Soil Taxonomy, Vol. II. The Soil Orders. L.P. Wilding, N.E. Smeck, and G.F. Hall (eds.). Elsevier Sci. Publ. Comp., New York, pp. 217-252.

McLean, E. O. 1982. Soil pH and lime requirement. In Methods of Soil Analysis, Part 2, 2nd Ed. Chemical and Microbiological Properties. Agronomy monogr. No. 9. A.L. Page et al. (eds.). ASA and SSSA, Madison, WI, pp. 199-224.

McSweeney, K., and E. A. FitzPatrick. 1990. Microscopic characterization of the Spodic horizon. In Proc. 5th Int. Soil Correlation Meeting (V-ISCOM): Characterization, Classification and Utilization of Spodosols. J.M. Kimble and R.D. Yeck (eds.). USDA-SCS and Soil Management Support Service, pp. 211-220.

Mehra, O. P., and M. L. Jackson. 1960. Iron oxides removed from soils and clays by a dithionite-citrate system buffered with sodium bicarbonate. Clays Clay Miner 7:317-327.

Miller, B. J. 1983. Ultisols. In Pedogenesis and soil taxonomy: Vol. II. The Soil Orders. L.P. Wilding, N.E. Smeck, and G.F. Hall (eds.). Elsevier Sci. Publ. Comp., New York, pp. 283-323.

Mokma, D. L. 1993. Color and amorphous materials in
Spodosols from Michigan. Soil Sci. Soc. Am. J. 57:125-138.

Nelson, D. W., and L. E. Sommers. 1982. Total carbon, organic carbon, and organic matter. In Methods of Soil Analysis, Part 2, 2nd Ed. Chemical and Microbiological Properties. Agron. Monogr. No. 9. A. L. Page et al. (eds.). ASA and SSSA. Madison, WI, pp. 539-577.

Rich, C. I. 1968. Hydroxy interlayers in expansible layer silicates. Clays Clay Miner 16:15-30.

Ross, G. J. 1975. Experimental alteration of chlorites into vermiculite by chemical oxidation. Nature 255:133-134.

Ross, G. J., C. Wang, and H. Kodama. 1990. Mineralogy of Spodosols. In Proc. 5th Int. Soil Correlation Mtg. (V-ISCOM): Characterization, Classification and Utilization of Spodosols. J.M. Kimble and R.D. Yeck (eds.). USDA-SCS and Soil Management Support Service, pp. 289-302.

Ross, G. J., and H. Kodama. 1974. Experimental transformation of a chlorite into a vermiculite. Clays Clay Miner 22:205-211.

Ross, G. J., and M. M. Mortland. 1966. A soil beidellite. Soil Sci. Soc. Am. Proc. 30:337-343.

Rourke, R. V. 1991. ICOMOD Circular Letter No. 10. International Committee on the Classification of Spodosols. Soil Conservation Service, USDA.

Sawhney, B. L. 1989. Interstratification in layer silicates. In Minerals in Soil Environments. J.B. Dixon and S.B. Weed (eds.). SSSA, Madison, WI, pp. 789828.

Soil Survey Staff. 1993. Examination and Description of Soils. Soil Survey Manual. USDA Handbook No. 18. USDA-SCS, Washington, DC, pp. 59-196.

Soil Survey Staff. 1999. Soil taxonomy: A basic system of soil classification for making and interpreting soil surveys, 2nd Ed. USDA, Agric. Handbook No. 436. US Govt. Print. Office, Washington, DC.

Thomas, G. W. 1982. Exchangeable cation. In Methods of Soil Analysis, Part 2. Chemical and Microbiological Properties, 2nd Ed. Agronomy Monogr. No. 9. A.L. Page et al. (eds.). ASA and SSSA, Madison, WI, pp. 149-157.

Vicente, M. A., M. Razzaghe, and M. Robert. 1977. Formation of aluminum hydroxy vermiculite (intergrade) and smectite from mica under acidic conditions. Clay Miner. 12:101-112.

Wang, C., G. J. Ross, and R. Protz. 1989. Effect of crystalline iron oxides on development and classification of podzolic soils in western Labrador, New Foundland. Soil Sci. Soc Am. J. 53:870-875.

Wang, C., and J. A. McKeague. 1982. Illuviated clay in sandy podzolic soils of New Brunswick. Can.J. Soil Sci. 62:79-89. 